Władysław T. Miodunka

Uniwersytet Jagielloński, Kraków

w.miodunka@uj.edu.pl

\title{
DWUJĘZYCZNOŚĆ POLSKO-OBCA W POLSCE I POZA JEJ GRANICAMI. ROZWÓJ I PERSPEKTYWY BADAŃ
}

Słowa klucze: bilingwizm, wielojęzyczność, język polski, język mniejszości narodowej, język mniejszości etnicznej, język zbiorowości polskiej poza Polską, historia języka polskiego

Keywords: bilingualism, multilingualism, Polish, language of national minority, language of ethnic minority, language of Polish community outside Poland, history of the Polish language

Patrząc dziś na badania dwujęzyczności polsko-obcej, musimy zauważyć zmianę miejsca tych badań w ogólnej produkcji naukowej z zakresu lingwistyki polonistycznej. Ta zmiana miejsca to z jednej strony rezultat wzrostu liczby prac poświęconych bilingwizmowi po roku 2000, z drugiej - wynik zmian stopniowo dokonujących się w metodologii badań językoznawczych w Polsce. Oba czynniki są na tyle ważne, że warto przyjrzeć im się bardziej szczegółowo.

Pisząc o rozwoju badań uwzględnimy, także te prace, których autorzy nie deklarują wprawdzie bezpośredniego zainteresowania badaniem bilingwizmu, ale które przynoszą wiele informacji na temat przeszłej lub obecnej dwujęzyczności polsko-obcej.

\section{Dotychczasowe badania dwujęzyczności polsko-obcej}

1.1. Omawiając w książce Bilingwizm polsko-portugalski w Brazylii (2003) polskie badania bilingwizmu, odwoływałem się do trzech książek i kilku artykułów. Omawiane 
książki to monografia Bronisławy Ligary (1987), opracowanie Marii Teresy Michalewskiej (1991) oraz książka Ewy Lipińskiej (2003). Ponadto zwracałem uwagę na socjologiczną monografię badaczy australijskich, Rogera McL. Harrisa i Jerzego Smolicza (1984), którzy uwzględniali znajomość języków angielskiego i polskiego w skonstruowanych przez siebie skalach etniczności i asymilacji (Miodunka 2003: 85-95). Wśród omówionych w książce artykułów znalazł się bardzo interesujący artykuł Anny Wierzbickiej Podwójne życie człowieka dwujęzycznego (tłum. pol. zob.: Miodunka 199ob). Podstawę analizy lingwistycznej autorki stanowił stan świadomości i odczucia związane z używaniem przez nią samą dwu języków - polskiego i angielskiego, a tezy wyjściowe tej analizy sprowadzały się do dwu bardzo istotnych stwierdzeń:

a) gdy ktoś przechodzi z jednego języka na drugi, to nie tylko forma się zmienia, ale również i treść;

b) języki różnią się między sobą nie tylko jako systemy językowe, ale również jako światy kulturowe, jako nośniki etnicznej tożsamości (Wierzbicka 1990: 71).

W podsumowaniu omówienia istniejących prac stwierdziłem, że

[...] prac językoznawczych na temat bilingwizmu nie ma dużo, są to jednak prace znaczące albo ze względu na autora o renomie międzynarodowej (zob. prace A. Wierzbickiej i J. Smolicza), albo ze względu na osobę, której bilingwizm poddano analizie (zob. pracę na temat bilingwizmu Z. Krasińskiego). W jednym przypadku (grupy emigrantów polskich do Niemiec $\mathrm{z}$ lat 8o.) poddano analizie grupę typową dla współczesnej emigracji z Polski, stawiając bardzo ważne pytania o możliwość szybkiego nauczenia się języka kraju osiedlenia, a z drugiej strony - o szanse zachowania języka polskiego. Podobny charakter miały badania E. Lipińskiej, prowadzone w Australii (Miodunka 2003: 94-95).

$\mathrm{W}$ związku z tym postulowałem podejmowanie nowych badań bilingwizmu, szczególnie takich, które powiążą analizę lingwistyczną z analizą o charakterze psychologicznym i socjokulturowym, podkreślając równocześnie, że krajem, gdzie takie badania warto podjąć, są Stany Zjednoczone, zwłaszcza metropolia Chicago, do której wyjeżdża wciąż duża grupa polskich emigrantów.

Wracając do badanej grupy emigrantów polskich do Niemiec z lat 8o., należy dodać, że mowa tu była o bardzo ciekawej, ale niepublikowanej w całości pracy doktorskiej Małgorzaty Warchoł-Schlottmann (1994). Autorce udało się jednak opublikować w latach 90. dwa artykuły wykorzystujące rezultaty przeprowadzonych badań (por. Schlottmann 1995; Warchoł-Schlottmann 1996).

1.2.1. Należy podkreślić, że w następnym dziesięcioleciu ukazało się kilka książek poświęconych dwujęzyczności, powstałych w różnych ośrodkach akademickich, co ma swoje duże znaczenie. Chodzi tu o prace Elżbiety Czykwin i Doroty Misiejuk (2002), Krystyny Wróblewskiej-Pawlak (2004), Jadwigi Cieszyńskiej (2006), Katarzyny Kainacher (2007), Romana Laskowskiego (2009) i Roberta Dębskiego (2009). 
Już same ich tytuły świadczą o tym, że każdy z autorów analizuje zjawisko bilingwizmu z odmiennego punktu widzenia, patrząc na samą dwujęzyczność przede wszystkim jako na zjawisko grupowe, ale nie unikając studiów przypadków, jeśli ciekawe przypadki znajdują się w jego zasięgu. Wśród wymienionych prac wyróżnia się książka E. Czykwin i D. Misiejuk, ponieważ dotyczy dwujęzyczności przedstawicieli dwu mniejszości narodowych w Polsce - białoruskiej i ukraińskiej. Pozostałe książki dotyczą dwujęzyczności polsko-obcej poza granicami naszego kraju: polsko-angielskiej w Australii (Dębski i Lipińska), polsko-niemieckiej w Austrii (Cieszyńska i Kainacher), polsko-francuskiej (Wróblewska-Pawlak), polsko-szwedzkiej (Laskowski) i polsko-portugalskiej (Miodunka). Optymizm budzi fakt, że większość z tych prac jest poświęcona bilingwizmowi dzieci i młodzieży (Czykwin i Misiejuk, Lipińska, Cieszyńska, Kainacher, Laskowski). Ich autorzy zwracają dużą uwagę na zagrożenie języka etnicznego wśród członków badanej grupy, to znaczy języków białoruskiego (Czykwin), ukraińskiego (Misiejuk) i polskiego (Lipińska, Cieszyńska, Kainacher, Laskowski). Najpoważniejsze ostrzeżenie sformułował w tym względzie R. Laskowski, który zagrożenie znajomości języka etnicznego umieścił w tytule swej książki (zob. też Laskowski 2009: 15-82, 223-226).

Analizie tych prac wraz z książkami W.T. Miodunki i E. Lipińskiej poświęciłem artykuł (Miodunka 2010a). W jego zakończeniu zawarłem następujące stwierdzenie:

Ostatnie dziesięciolecie to okres wzmożonego zainteresowania dwujęzycznością. Wprawdzie omawiane prace funkcjonują jakby na marginesie zasadniczych zainteresowań polskiej lingwistyki, powinny się one jednak znaleźć w jej głównym nurcie, gdyż to właśnie one są najbliższe nowego paradygmatu w humanistyce, jakim stała się komunikacja międzykulturowa. Język odgrywa w komunikacji międzykulturowej w dalszym ciągu zasadniczą rolę, choć nacisk kładzie się nie na język jako system złożony z podsystemów, ale na język jako narzędzie budowania własnej tożsamości i walencji kulturowej, jako narzędzie tworzenia i odbioru kultury, jako podstawę każdej kultury (Miodunka 2010a: 68).

1.2.2. W roku 2011 ukazała się monografia Marzeny Błasiak Dwujęzyczność i ponglish. Zjawiska językowo-kulturowe polskiej emigracji w Wielkiej Brytanii. Mimo że w podtytule książki autorka użyła terminu emigracja, jej praca odnosi się do najnowszej (poakcesyjnej) polskiej migracji do Wielkiej Brytanii. Przedmiotem analizy Błasiak uczyniła dwa zjawiska: 1) „dwujęzyczność polsko-angielską najmłodszej polskiej migracji”; 2) „ponglish, czyli mieszany (polsko-angielski) kod językowy, który zyskuje coraz większe rzesze użytkowników na Wyspach" (Błasiak 2011: 8).

W wyniku przeprowadzonych w latach 2007-2009 badań dwujęzyczności zbiorowej (128 osób) i indywidualnej (6 osób) polskich migrantów na Wyspach autorka doszła do wniosku, że w Wielkiej Brytanii mamy do czynienia z niezrównoważoną dwujęzycznością polsko-angielską, w której językiem dominującym jest polszczyzna, a język angielski występuje jako język drugi funkcjonalnie, choć to jego znajomość 
jest stale doskonalona głównie w pracy lub w szkole (na studiach), ale także w kontaktach z Brytyjczykami. W sumie ponad 88\% respondentów uznało, że używa wymiennie obu języków.

Podobnie sprawa wygląda w przypadku tożsamości i sytuacji kulturowej Polaków na Wyspach, które Błasiak podsumowuje w taki sposób:

$\mathrm{Z}$ wypowiedzi migrantów biorących udział w badaniach wynika, że identyfikują się oni z różnymi grupami (już nie tylko z polską społecznością, ale również, przez pewną selekcję elementów kultury, ze społecznością brytyjską). Ta identyfikacja prowadzi do zmiany autopercepcji, redefinicji własnej tożsamości i utworzenia się nowej tożsamości człowieka pogranicza [...]. W przypadku polskich migrantów „rdzeniem” czy też „filarem” nowej tożsamości jest polskość, która wzbogacona została o elementy kultury brytyjskiej (Błasiak 2011: 122; podkr. - W.M).

Analizując bilingwizm indywidualny sześciu osób, autorka uwzględnia ich samooceny znajomości każdego z języków, polegające na przypisaniu każdej sprawności stopnia jej znajomości, wynikającego ze standardów europejskich zawartych w tzw. Europassie (podstawowego - A1, A2; średniego - B1, B2; zaawansowanego - C1, C2). Ta decyzja musi budzić mieszane reakcje: $\mathrm{z}$ jednej strony trzeba pochwalić autorkę za uwzględnienie poziomów zawartych w standardach europejskich, $\mathrm{z}$ drugiej trzeba powiedzieć, że tak wyraźne określenie poziomów znajomości poszczególnych sprawności będzie budzić poważne wątpliwości wszystkich tych, którzy zajmują się testowaniem i potwierdzaniem w procesie certyfikacji znajomości języków obcych (por. Miodunka 2013a).

Ciekawą częścią pracy Błasiak jest rozdział szósty, przedstawiający cechy mowy bilingwalnej oraz zagadnienie odmiany polszczyzny nazywanej ponglish. W podsumowaniu analizy autorka dochodzi do takich stwierdzeń:

Zaledwie co czwarty Polak w Wielkiej Brytanii przyznaje się do używania w rozmowach $\mathrm{z}$ rodakami na emigracji dialektu polsko-angielskiego, jakim jest ponglish. Specyfiką tego kodu, powstałego w warunkach bilingwizmu, są liczne hybrydy językowe zbudowane z elementów zaczerpniętych bądź to z polszczyzny standardowej oraz różnych jej wariantów środowiskowych czy stylowych, bądź z języka angielskiego (i jego wariantów). Ponglish, jako wynik polsko-angielskich kontaktów językowo-kulturowych, odzwierciedla tygiel środowiskowy, w którym żyją jego użytkownicy. Dwie najważniejsze funkcje, jakie spełnia, to funkcja jednocząca (konsoliduje polskich emigrantów na Wyspach) oraz funkcja separująca (pozwala polskiej grupie migracyjnej zaakcentować własną odrębność). Ponglish jest czynnikiem pozwalającym identyfikować się z określoną grupą społeczną - w omawianym przypadku to polska diaspora w Wielkiej Brytanii (Błasiak 2011: 176; podkr. - W.M).

Omawiana monografia Błasiak jest pracą godną uwagi, ponieważ odnosi się ona do największej polskiej zbiorowości migracyjnej, jaka powstała w ramach Unii Europejskiej po wejściu do niej naszego kraju w 2004 r. Zmienione warunki funkcjonowania tej 
zbiorowości w UE spowodowały zmiany w świadomości mówiących po polsku, co widać w ich podejściu do obu języków, do zjawiska dwu- i wielojęzyczności, do ponglish, a także do dwu kultur oraz do redefinicji tożsamości polskiej w kraju należącym do UE. Warto wracać do tej tematyki w przyszłości, by zobaczyć, w jakim kierunku potoczą się obserwowane dziś przemiany językowe, kulturowe i świadomościowe.

\section{Polskie definicje dwujęzyczności}

2.1. Fakt, że prac na temat dwujęzyczności jest coraz więcej, ale znajdują się one poza głównym nurtem zainteresowań polskiej lingwistyki, można tłumaczyć na wiele sposobów, z których najbardziej prawdopodobnym będzie zapewne stwierdzenie, że językoznawcy reagują zwykle na zjawiska językowe najczęściej obserwowane w życiu społecznym. Ponieważ po roku 1945 społeczeństwo polskie stało się - przynajmniej oficjalnie - społeczeństwem niemal wyłącznie polskojęzycznym, nie poświęcano bilingwizmowi większej uwagi.

Świadczy o tym między innymi definicja dwujęzyczności zawarta w EJO (1999), sprowadzająca ją do posługiwania się na co dzień przez daną grupę społeczną dwoma różnymi językami.

Dwujęzyczność wytwarza się na terenach o mieszanym składzie etnicznym. Konieczność współżycia na co dzień zmusza przedstawicieli jednej narodowości do używania oprócz swojego języka ojczystego również języka drugiej grupy etnicznej [...] (EJO 1999: 130).

Ponieważ definicji bilingwizmu jest bardzo dużo, K. Wróblewska-Pawlak za Maurice'em van Overbeke'em dzieli je na trzy typy: na definicje opisowe, normatywne i metodologiczne (Wróblewska-Pawlak 2004: 19-34). Cytowana definicja należy do grupy definicji opisowych, ponieważ autor opisuje dwujęzyczność, wyliczając najważniejsze cechy definiowanego zjawiska: koncentrując się na dwujęzyczności grupowej, pomija zupełnie dwujęzyczność indywidualną, choć nie każdy bilingwizm indywidualny mieściłby się w tak zdefiniowanym przez niego bilingwizmie zbiorowym. Podając przykłady krajów, gdzie mamy najczęściej do czynienia z dwujęzycznością grupową, podaje Szwajcarię (bilingwizm niemiecko-francuski), Belgię (bilingwizm flamandzko-francuski) i byłą Jugosławię (bilingwizm albańsko-serbski, włosko-serbskochorwacki i albańsko-macedoński). Mówiąc o dwujęzyczności Polaków, wymienia Polaków w byłej Rzeszy niemieckiej na Śląsku, Pomorzu, Warmii i Mazurach, pomijając zupełnie bilingwizm polsko-obcy w krajach osiedlenia zbiorowości polonijnych oraz dwujęzyczność przedstawicieli mniejszości narodowych zamieszkałych w Polsce (np. Białorusinów, Ukraińców, Słowaków, Czechów, Niemców, Litwinów, Łemków, Romów i Żydów). Odwołując się do badań dwujęzyczności, autor definicji słusznie zwraca uwagę na znaczący dorobek językoznawstwa amerykańskiego i wymienia fundamentalne prace Einara Haugena i Uriela Weinreicha, obie z 1953 r., nie wspominając 
natomiast późniejszych prac europejskich czy na przykład australijskich, mimo osiągniętych przez nie pozycji prac podstawowych.

2.2. Definicja zawarta w EJO jest bardzo podobna do definicji dwujęzyczności napisanej przez tego samego autora, a zawartej w EJP (1994: 72), choć krótsza od niej. Jeśli uwzględnimy fakt, że definicja ta znalazła się w obu wydaniach EJP, stwierdzimy, że definicja pochodzi prawdopodobnie z połowy lat 7o. wieku XX. Ponieważ w ciągu 40 lat zmieniło się całe językoznawstwo, a szczególnie rozwinęła się polska socjolingwistyka, postulujemy przygotowanie nowych encyklopedii lingwistyki i języka polskiego, opisujących aktualny stan badań i wiedzy na temat językoznawstwa w ogóle, a języka polskiego w świecie i polszczyzny jako języka obcego, drugiego, dziedziczonego - w szczególności.

2.3. Stosunkowo dużą popularność zyskała definicja dwujęzyczności zaproponowana przez Lipińską, brzmiąca tak:

Dwujęzyczność to opanowanie dwu języków w takim stopniu, jak społecznie ekwiwalentni ich jednojęzyczni nosiciele, czyli ambilingwizm. Polega na umiejętności posługiwania się wszystkimi sprawnościami w języku ojczystym i drugim oraz na częstym używaniu obydwu języków w różnych sytuacjach i z różnymi uczestnikami aktu komunikacji. Jest to zazwyczaj nietrwały stan, mający związek z emigracją lub pobytem za granicą, co implikuje bliski kontakt $\mathrm{z}$ danym językiem i kulturą, umożliwiający ich doznawania (Lipińska 2003: 115).

O tej definicji trzeba powiedzieć, że jest to definicja normatywna, gdyż najpierw ustala, jakie warunki musi spełniać osoba dwujęzyczna, zanim badacz uzna ją za dwujęzyczną i podda badaniom. Definicję tę można by stosować do badań bilingwizmu indywidualnego, natomiast nie nadaje się ona do badań dwujęzyczności zbiorowej, kiedy z góry należy zakładać różny stopień znajomości każdego z dwu języków u poszczególnych członków grupy.

W minionym roku sprawa definicji takich terminów jak język ojczysty, język obcy, bilingwizm (dwujęzyczność) wzbudziła dyskusję dzięki artykułom koncentrującym się na zagadnieniach terminologicznych (Cockiewicz 2013; Miodunka 2013b).

\section{Dwujęzyczność przedstawicieli mniejszości narodowych i etnicznych na ziemiach polskich}

3.1. Omawiane dotąd prace odnosiły się do polszczyzny używanej obecnie w naszym kraju i poza jego granicami, choć samo zjawisko dwu- i wielojęzyczności jest znane także z historii języka polskiego, jakkolwiek ogólne opracowania nie uwzględniają go w wystarczającym stopniu. Dlatego koniecznie trzeba tu uwzględnić prace 
dwu autorek krakowskich, które od lat konsekwentnie zajmują się dwu- i wielojęzycznością (członków) społeczeństwa polskiego. Pierwszą z nich jest Maria Strycharska-Brzezina, która od 1979 r. zajmuje się między innymi opisywaniem języka polskiego używanego w ciągu wieków przez mniejszości narodowe w Polsce, analizując w tym celu utwory literackie i folklorystyczne, ale nie zapominając przy tym, że przedstawiciele mniejszości i grup etnicznych byli rodzimymi użytkownikami innych języków. Omówienie dorobku naukowego i bibliografię jej prac zob. (Gruchała, Kurek 2010; Miodunka 2010b). To ona we wstępie do swej pierwszej ważnej monografii Polszczyzna Żydów z 1986 r. napisała:

Dzieje języka polskiego to również w pewnej mierze dzieje asymilacji językowej zamieszkałych w Polsce cudzoziemców. W przyszłej, nowoczesnej historii języka polskiego musi się znaleźć więcej miejsca dla zagadnień socjolingwistycznych, m.in. dla siły asymilacyjnej polszczyzny (Brzezina 1986: 7-8).

Zwracamy uwagę na jej słuszny postulat dotyczący uwzględnienia w nowej syntezie historii języka polskiego polszczyzny grup mniejszościowych, ponieważ mimo upływu 30 lat od jego sformułowania (praca została oddana do druku w 1983 r.) nie został on dotąd zrealizowany. Jej określenie siła asymilacyjna polszczyzny można uznać za synonimiczne nazwanie mocy języka polskiego, przyciągającej do poznania naszego języka i kultury przedstawicieli mniejszości narodowych, grup etnicznych oraz cudzoziemców (zob. Miodunka 1990a). Natomiast należy zgodzić się z Brzezinową, kiedy zauważa, że nie opisując polszczyzny mniejszości narodowych, językoznawcy polscy nie brali pod uwagę mocy naszego języka, która była znaczna i która mogłaby w pewnym stopniu zmienić ogólne spojrzenie na historię polszczyzny.

3.2. Należy zwrócić uwagę na fakt, że tytuły prac Brzezinowej mówią zwykle o polszczyźnie danej mniejszości narodowej lub etnicznej. Tymczasem prace te zawierają podsumowanie stanu badań odnoszących się do opisywanej mniejszości, dzięki czemu możemy dowiedzieć się dużo o samej mniejszości i jej języku. Tak wygląda to w cytowanej monografii, którą można uznać za swoisty model kompozycyjny dla całego cyklu prac poświęconych polszczyźnie mniejszości narodowych i etnicznych. Jej część pierwszą stanowią prolegomena lingwistyczne, czyli informacje o językach żydowskich na ziemiach polskich i o stanie badań nad kontaktami językowymi słowiańsko-żydowskimi. Dalej znajduje się omówienie slawizacji jidysz, poloniców w jidysz oraz judaiców w polszczyźnie. Potem następują prolegomena socjolingwistyczne, czyli historia osadnictwa żydowskiego na ziemiach polskich, przedstawienie etapów asymilacji językowej Żydów i ich sytuacji językowej w świetle utworów literackich. Część pierwszą kończą prolegomena filologiczne, zawierające dzieje językowej stylizacji żydowskiej. Główną część omawianej monografii stanowi część druga przynosząca przegląd językowych cech żydowskich w tekstach stylizowanych (w zakresie fonetyki, fleksji, słowotwórstwa, składni, słownictwa i frazeologii oraz stylu). Końcowe części 
pracy to analiza geograficznych uwarunkowań polszczyzny Żydów, czyli przedstawienie polszczyzny Żydów z Polski etnicznej, z Kresów południowo-wschodnich i z Litwy, a potem ukazanie techniki stylizacji językowej w dwu typach stylizacji: realistycznej i deformującej.

3.3. Że pisząc na przykład o polszczyźnie Niemców, Brzezinowa nie traciła z oczu perspektywy ich dwujęzyczności, pokażemy na przykładzie jej monografii z $1989 \mathrm{r}$. Autorka widziała w niej dwujęzyczność niemiecko-polską jako pewne kontinuum, w którym wyróżniała następujące punkty: 1) jednojęzyczność niemiecką, 2) dwujęzyczność niemiecko-polską z wyraźną dominacją języka niemieckiego (niemiecki używany jako język podstawowy jednostki, która dysponuje bierną znajomością polszczyzny w różnym zakresie), 3) dwujęzyczność niemiecko-polską (mówiący wykazują się znajomością języka niemieckiego obok czynnej i biernej znajomości polszczyzny), wreszcie 4) jednojęzyczność polską (z ewentualnością używania niemieckiego jako języka obcego). W przypadku czynnej znajomości polszczyzny autorka wyróżniała:

[...] bilingwizm zmieszany (posługiwanie się polszczyzną interferowaną językiem niemieckim przy równoczesnym myśleniu i mówieniu po niemiecku; polszczyzna jest w tym wypadku językiem drugim) oraz bilingwizm niezmieszany (myślenie i mówienie zarówno po polsku, jak i po niemiecku) (Brzezina 1989: 66-67).

Należy doprecyzować, że kiedy autorka mówiła o bilingwizmie zmieszanym, miała na myśli dwujęzyczność niemiecko-polską z dominacją języka niemieckiego (polszczyzna jest używana jako język drugi), kiedy zaś mówiła o bilingwizmie niezmieszanym, wyróżniała dwujęzyczność niemiecko-polską o charakterze zrównoważonym.

3.4. Bardzo dobrze się stało, że w tomie Polszczyzna 2000 (Pisarek 1999) znalazło się opracowanie Wojciecha Kajtocha. Ze względu na nowatorstwo przyjętego w tym tomie rozwiązania warto także zauważyć, iż we wstępie jego redaktor, Walery Pisarek, nazywa to opracowanie „naturalnym a nieodzownym uzupełnieniem [...] 15 opracowań o współczesnej polszczyźnie" (ibid.: 9). W swym opracowaniu Kajtoch koncentruje się na sytuacji prawnej i warunkach rozwoju języków mniejszości narodowych, szczegółowo zaś omawia sytuację języków białoruskiego, czeskiego, hebrajskiego i jidysz, litewskiego, łemkowskiego, niemieckiego, romani, rosyjskiego (gwary staroobrzędowców), słowackiego i ukraińskiego (Kajtoch 1999: 279-305). W zakończeniu opracowania Kajtoch pisze krótko o polszczyźnie mniejszości narodowych, przywołując omówione tu wcześniej prace M. Brzezinowej oraz informując o podejmowanych w tym zakresie badaniach współczesnych, które rozpoczęły się właściwie w ostatnim dwudziestoleciu XX w. od badań Elżbiety Smułkowej (1990). Istotne jest jednak to, że wszystkie przywoływane prace, z pracą Kajtocha włącznie, postrzegają języki mniejszości narodowych jako osobny problem językoznawczy, 
istniejący niejako obok używanej przez te mniejszości polszczyzny. Taki stan rzeczy można tłumaczyć dominującym wówczas etniczno-genealogicznym rozumieniem narodu oraz troską o dobro narodowe, jakim jest język, które wyraźnie przeważały nad naukowymi zainteresowaniami językami mniejszości i zagadnieniem ich bilingwizmu (por. Miodunka 2011). Poza tym w zgodzie z obowiązującą specjalizacją o językach słowiańskich powinni byli pisać raczej slawiści, o germańskich - germaniści, a o polszczyźnie - poloniści, nawet jeśli nie tracili oni z oczu innych języków używanych na badanym przez nich terenie. Przekroczenie tej „bariery kompetencyjnej" nastąpiło dopiero około roku $2000 \mathrm{w}$ związku z prowadzonymi badaniami dwui wielojęzyczności. Perspektywę dwu- i wielojęzyczności przyjęli w zasadzie dopiero Zbigniew Greń (200o; por. 4.2.) oraz E. Czykwin, która stwierdziła, „iż białoruski jest obok polskiego drugim językiem ojczystym, nie zaś językiem obcym” mniejszości białoruskiej w Polsce (Czykwin, Misiejuk 2002: 29-30).

\section{W stronę opisu wielojęzyczności I, II i III Rzeczypospolitej}

4.1. Podsumowanie prac Strycharskiej-Brzeziny, dotyczących polszczyzny mniejszości narodowych i etnicznych, przyniósł tom Socjostylistyka a dzieje literatury polskiej, który otwiera praca Języki mniejszości narodowych i etnicznych w Polsce, przedstawiająca stan badań nad tymi językami przed II wojną światową oraz w okresie powojennym (Strycharska-Brzezina 2009: 9-19). W tomie tym znajdujemy między innymi artykuł Koegzystencja języków etnicznych na Kresach Wschodnich w świetle utworów literackich, zawierający hierarchiczne matryce używania języków na Kresach Wschodnich w czasach I Rzeczypospolitej, w okresie zaborów i w II RP, czyli w istocie obraz dwu- lub trójjęzyczności na tych ziemiach w ciągu kilku wieków (ibid.: 20-36). Przykładowo przytaczamy matrycę wielojęzyczności z czasów I Rzeczypospolitej na ziemiach Wielkiego Księstwa Litewskiego:

I język polski (etnolekt; język państwowy, elitarny, kontaktowy);

II etnolekty autochtoniczne (bałtyckie i wschodniosłowiańskie);

III etnolekty allochtoniczne (enklawowe/wyspowe: ormiański, tatarski, karaimski, niemiecki, rosyjski starowierców oraz języki rozproszone: jidysz i cygański).

Zgodnie ze strategią komunikowania społecznego użytkownicy języków z poziomów II i III powinni byli znać ważny w danym regionie język poziomu wyższego (przynajmniej jego odmianę mówioną). Prowadziło to prawdopodobnie do dwujęzyczności na poziomie II i trójjęzyczności na poziomie III. Nie ulega wątpliwości, że dla osób używających języków z poziomów II i III jako ojczystych - polszczyzna była językiem drugim, przyswajanym w wyniku kontaktów z osobami i grupami mówiącymi po polsku. Język polski dysponował wówczas znaczną mocą, najpierw jako 
język kontaktowy, potem - państwowy i wreszcie elitarny. Mówić po polsku, używać polszczyzny literackiej znaczyło wtedy aspirować do elity albo należeć do niej.

Ta praca Strycharskiej-Brzeziny stanowi w pewnym sensie uszczegółowienie rozważań Józefa Reczka na temat języków używanych w dawnej Rzeczypospolitej (Reczek 1989, 1994).

4.2. Pisząc o wielojęzyczności Rzeczypospolitej Polskiej, warto zwrócić uwagę na monografię Grenia (200o). W wyniku analizy dokumentów pisanych ze Śląska Cieszyńskiego autor wyróżnia następujące okresy używania języków, zwanych oficjalnymi: 1) okres jednojęzyczny, kiedy w dokumentach pisanych panuje łacina; 2) okres dwujęzyczny, kiedy dokumenty redagowano po łacinie lub po niemiecku, trwający od 1331 do 1440 r.; 3) okres trójjęzyczny, dzielony na cztery fazy, kiedy do redagowania dokumentów używano łaciny oraz w zmiennym stopniu języków niemieckiego, czeskiego i polskiego; okres ten trwał od 1440 do XIX w. włącznie (Greń 200o: 21-36). Większa część tej cennej monografii została poświęcona polszczyźnie cieszyńskiej, najpierw historii języka ludowego, potem jego obecności w dokumentach pisanych, wreszcie współczesnemu zakresowi używania przez młodzież gwary cieszyńskiej w opozycji do języka literackiego (polskiego lub czeskiego). W rezultacie dysponujemy nowatorskim metodologicznie, a także wnikliwym merytorycznie studium obecnej dyglosji na Śląsku Cieszyńskim, zarówno w granicach Polski, jak i Czech (ibid.: 36-285; por. też 6.1.).

4.3. Nie przez przypadek zestawiamy tu pracę Strycharskiej-Brzeziny na temat wielojęzyczności w Wielkim Księstwie Litewskim z pracami Reczka o wielojęzyczności w czasach I Rzeczypospolitej, a także z pracą Grenia odnoszącą się do dwu- i wielojęzyczności oraz dyglosji na Śląsku Cieszyńskim. Chcemy w ten sposób zwrócić uwagę na potrzebę prac opisujących stosunki między językami używanymi w poszczególnych regionach I i II Rzeczypospolitej. Rzeczpospolita Polska była bowiem wtedy organizmem państwowym zbyt rozległym terytorialnie, żeby opis panującej w jej granicach wielojęzyczności można było zamknąć w jednym, zwięzłym opracowaniu. Takie prace jak omawiane w tym miejscu pokazują nam prawdziwy obraz tej wielojęzyczności, uwarunkowanej politycznie, ekonomicznie, regionalnie, społecznie i psychologicznie (por. też Greń 2012). Prace te zbliżają nas do opisu zjawiska wielojęzyczności Rzeczypospolitej Polskiej, zarówno w jej historycznym, jak i współczesnym kształcie. Pokażą nam też dziedzictwo językowe wieków, jeśli będziemy na nie wystarczająco wrażliwi i zechcemy je zobaczyć.

4.4. W tę perspektywę badań wielojęzyczności historycznej i współczesnej, uwarunkowanej regionalnie, dobrze wpisuje się program badań języków i wspólnoty językowej na Śląsku, przedstawiony w artykule Bogusława Wyderki (2011: 387). Taka nowa synteza jest konieczna, gdyż - jak słusznie podkreśla autor - przez dziesięciolecia 
wiedza o Śląsku była wykorzystywana w polsko-niemieckiej wojnie propagandowej i dlatego była traktowana selektywnie. Także dziś nie jest ona wolna od uwarunkowań ideologicznych, widocznych w pracach części uczonych niemieckich, polskich i tak zwanych autonomistów śląskich.

\section{Dwujęzyczność twórców literatury polskiej}

5.1. Pisząc o polszczyźnie przedstawicieli mniejszości narodowych i etnicznych na historycznych ziemiach państwa polskiego, Strycharska-Brzezina pamiętała o ich bilingwizmie grupowym oraz o jego zróżnicowaniu. Dominująca w jej publikacjach kwestia znajomości polszczyzny oraz bilingwizmu grupowego zasadniczo różni jej prace od publikacji innej autorki, koncentrującej się na analizie bilingwizmu indywidualnego polskich pisarzy i poetów. Tą krakowską badaczką, której prace chcemy ogólnie zaprezentować, jest Bronisława Ligara. Jej praca z zakresu historii języka polskiego (Ligara 1987) stanowi równocześnie pierwsze w polskiej lingwistyce studium przypadku dwujęzyczności polsko-francuskiej. Warto podkreślić, że chodzi o dwujęzyczność jednostki wybitnej i znaczącej w literaturze polskiej okresu romantyzmu, jaką był niewątpliwie Zygmunt Krasiński. We wprowadzeniu teoretycznym do analizy materiału autorka omówiła problematykę kontaktów językowych, badania bilingwizmu i zasady analizy galicyzmów. Ligara zwróciła uwagę na dwie przeciwstawne tendencje dające się zaobserwować w języku Krasińskiego: $\mathrm{z}$ jednej strony - swobodne przechodzenie z języka na język, będące źródłem interferencji indywidualnych i systemowych, z drugiej strony zaś - na hamowanie tych interferencji przez polską świadomość językową. Określiwszy dwujęzyczność Krasińskiego jako bilingwizm aktywny, Ligara podała, że interferencje indywidualne, typowe dla idiolektu Krasińskiego, składają się w $14 \%$ z galicyzmów formalnosemantycznych i aż w $42 \%$ z galicyzmów bez zapożyczania fonetycznej formy francuskiej.

5.2. Drugim dwujęzycznym poetą i pisarzem okresu romantyzmu, którego bilingwizm Ligara poddała analizie, jest Adam Mickiewicz - największy poeta tworzący w języku polskim. Mimo że o bilingwizmie Mickiewicza Ligara napisała kilka prac, ostatnie jej słowo stanowi zapewne artykuł z 2010 r. Swój artykuł rozpoczyna autorka od cytatu z pracy Wspólny język lingwistów i antropologów Romana Jakobsona (pol. przekł. 1989). Ten cytat, który warto przypomnieć także w tym artykule, brzmi: „Dwujęzyczność jest według mnie fundamentalnym problemem lingwistyki”. Warto przypomnieć, ponieważ w lingwistyce polskiej dwujęzyczność jako problem naukowy nie istniała przez wiele lat.

Omawiany artykuł liczy 30 stron, dlatego wyróżnimy tu tylko jego główne części: od wstępu poświęconego bilingwizmowi twórców literatury polskiej, postrzeganemu jako zagadnienie badawcze polskiego językoznawstwa, przez wnikliwą charakterystykę 
Mickiewicza jako osoby dwujęzycznej, po opis i analizę przejawów językowych zachowań Mickiewicza jako bilingwisty. Wśród tych zachowań, obserwowanych w Listach, znajdujemy przełączanie kodów polskiego i francuskiego, np.

Ale au Collège de France nie ma ani enceinte réservée, ani biletów, tak szanuja prawa równości (Ligara 2010: 151),

mieszanie obu kodów, np.

Miałem w pisaniu rozrywkę, a teraz $w$ nudach korekty niejakie contre-coup przeciw splinom gwałtownym, które mię często jak grajcarem w sercu wiercą (ibid.: 154),

wreszcie interferencje francuskie w zakresie słownictwa (interferencje formalnosemantyczne), np.

Pewny jestem, że znajdziesz sposób intymidacji księgarskiej na tego niepoczciwego edytora (ibid.: 157),

interferencje bez przeniesienia fonetycznej formy francuskiej, np. kalki wyrażeń frazeologicznych:

Żona moja ciagle cierpiaca, na koniec musiała się schronić w domu chorych; fr. maison des malades mentaux (ibid.: 158),

i składni, np.

Pójdź, proszę, sam do Ludwika. Może być, że on nie znajduje się w Paryżu; fr. il ne se trouve pas zamiast pol. nie ma go (ibid.: 163).

Już tych kilka przykładów zaczerpniętych z pracy Ligary dobrze pokazuje jej wielką dokładność w zakresie opisu i analizy kontrastywnej wszystkich przykładów pochodzących z listów Mickiewicza.

W podsumowaniu swego artykułu Ligara zastanawia się nad językiem twórcy literackiego w sytuacji bilingwizmu. Wychodzi od stwierdzenia, że dwujęzyczność Mickiewicza była najpierw przykładem bilingwizmu z dominacją języka ojczystego, ponieważ jego kompetencja w zakresie polszczyzny znacznie górowała nad znajomością języka francuskiego. Dopiero później, kiedy poeta mieszkał i pracował w Paryżu, jego bilingwizm zbliżał się do zrównoważonego; dochodziło wtedy do interferencji z języka francuskiego. Tę dominację języka francuskiego Ligara wiąże słusznie z rolami społecznymi, w których Mickiewicz występował w późniejszym okresie swego życia, oraz z niektórymi gatunkami tworzonych przezeń tekstów, stwierdzając:

Dla Mickiewicza francuszczyzna stała się z czasem językiem funkcjonalnie pierwszym, w którym wyrażał się jako dziennikarz, publicysta, polityk i wreszcie historyk literatury w dyskursie naukowym humanistycznym - w tych gatunkach dominujący okazał się u niego język francuski (ibid.: 167). 
W swych wnioskach autorka uwzględnia także fakt, że w trakcie analizy korzystała z listów poety, które jako gatunek cechują się dialogicznością, polegającą na tym, że powstają niejako w interakcji z odbiorcą. Na tej podstawie dochodzi do konkluzji, że odbiorcy listów byli ludźmi dwujęzycznymi, znającymi dobrze francuski:

Bilingwizm indywidualny poety implikował zatem bilingwizm ponadjednostkowy, zbiorowy, a przejawy zachowania językowego w postaci przemienności i mieszania kodów oraz interferencji mogły stać się w środowisku Wielkiej Emigracji swoistą „normą", do której osoby jednojęzyczne nie miały dostępu (ibid.: 167).

To ważne stwierdzenie Ligary prowadzi nas do wniosku, że na podstawie listów, zbliżonych przecież do języka spontanicznego, można by zrekonstruować polszczyznę mówioną przedstawicieli Wielkiej Emigracji, przynajmniej tej jej części, która była złożona z inteligencji. Wypada zauważyć również, iż te stwierdzenia Ligary znajdują pośrednie potwierdzenie w tym, co o odmianie ponglish we współczesnej Wielkiej Brytanii pisze Błasiak (por. 1.2.2.).

Tytuł cytowanego artykułu zapowiadał odwołanie się autorki do antropologii lingwistycznej, do czego wrócimy jeszcze w części metodologicznej tekstu. Tu natomiast chcemy przypomnieć jeden z końcowych wniosków Ligary, która pisze tak:

W przypadku Adama Mickiewicza doświadczenie życia w przestrzeni języka polskiego i francuskiego stanowiło genezę czerpania przez niego środków z tych dwóch kodów we własnej produkcji językowej, a dla niej odniesienie do abstrakcyjnej normy językowej przestaje być istotne (Ligara 2010: 167).

To nowe, zaskakujące zwolenników stosowania jednej normy językowej do wszystkich użytkowników polszczyzny, także do dwujęzycznych członków społeczeństwa, żyjących z dala od kraju, rozciąga Ligara na wszystkich twórców literatury polskiej, należących nie tylko do kręgów Wielkiej Emigracji, ale także do emigracji po 1945 r., której członkami byli tak znakomici twórcy, jak Witold Gombrowicz i Czesław Miłosz. Stwierdzenie to stoi w wyraźnej opozycji do stanowiska normatywnego Witolda Doroszewskiego z 1966 r. na temat galicyzmów w listach Mickiewicza.

5.3. Uważna lektura przedstawionych dotąd prac Ligary przekonuje nas, że pisząc o języku pojedynczych autorów, nie traciła ona z pola widzenia zagadnień szerszych: z jednej strony bilingwizmu zbiorowego członków Wielkiej Emigracji i emigracji polskiej w ogóle, $\mathrm{z}$ drugiej zaś - bilingwizmu pisarzy polskich niezależnie od epoki, w której tworzyli, i kraju, w którym żyli. Jej uwagi na ten temat były jednak rozproszone w różnych publikacjach i dlatego mogły umykać uwadze mniej uważnych czytelników. $\mathrm{Z}$ tego powodu dobrze się stało, że w 2011 r. ukazał się jej artykuł Bilingwizm twórców literatury polskiej jako problem badawczy historii języka, w którym stawia ona przed badaczami historii polszczyzny zagadnienie dwujęzyczności pisarzy jako osobne zadanie badawcze, dotąd albo całkowicie pomijane, albo ujmowane marginalnie. Postulując 
takie badania, odwołuje się ona z jednej strony do koncepcji socjolingwistyczno-komunikacyjnej historii języka polskiego, przedstawionej przez Stanisława Borawskiego (2000) i kontynuowanej przez Stanisława Dubisza (2009), z drugiej zaś do ujęć lingwistów francuskich, szczególnie Jeana-Marie Prieura (2006).

Autorka zwraca przede wszystkim uwagę na współistnienie w umyśle pisarza dwujęzycznego dwu kodów, co powoduje, że posługiwanie się w danym momencie tylko jednym z nich nie oznacza nieobecności w jego umyśle drugiego kodu. Równoczesna obecność dwu kodów sprawia, że autor dwujęzyczny podejmuje grę normami językowymi, nie poddając się wyłącznie normie swego języka ojczystego. Dalej Ligara podkreśla, że każdy dwujęzyczny twórca używa znanych sobie języków w trzech typach sytuacji komunikacyjnych: 1) w trakcie komunikacji z osobami jednojęzycznymi, znającymi jego język ojczysty (polski), ale nieznającymi języka drugiego (francuskiego); 2) w aktach komunikacji z osobami jednojęzycznymi, znającymi język drugi (francuski), a nieznającymi języka polskiego; 3 ) z osobami dwujęzycznymi, znającymi oba języki, zarówno polski, jak i francuski. Wydzielenie takich typów komunikacji pozwala pokazać, że Mickiewicz piszący utwory adresowane do wszystkich polskich czytelników, także tych nieznających francuszczyzny, poddawał się całkowicie presji normy języka polskiego. $Z$ drugiej strony ten sam autor piszący listy do ludzi ze środowiska Wielkiej Emigracji, znających dobrze oba języki, nie widział potrzeby podporządkowywania się presji normy językowej polszczyzny i korzystał na przykład z cytatów francuskich w trakcie przełączania kodów.

Swój artykuł Ligara kończy następującym stwierdzeniem:

Podstawowym problemem badawczym, jaki stawia bilingwizm wybitnych autorów, jest ukazanie tego, jak autor dwujęzyczny funkcjonował - w komunikowaniu się z otoczeniem i zawodowo jako twórca - między dwoma językami i dwoma kulturami literackimi. To między dwoma staje się obecnie jednym z najważniejszych wyzwań, jakie stawia współczesny paradygmat badań w humanistyce.

Prace, które zapoczątkowały badania nad bilingwizmem polsko-francuskim autorów romantycznych [...] wpisują się w zagadnienie bardziej ogólne: problem wyboru języka twórczości, obecny w historii literatury polskiej od czasów renesansu do czasów dzisiejszych. Ale dotychczasowa tradycja historycznoliteracka, a za nią historia języka polskiego postrzegała go w jednym tylko aspekcie: jako emancypację polszczyzny od dominacji innych języków. Warto jednak zbadać problem wyboru przez polskich autorów dwu- i kilkujęzycznych języka ich twórczości w innej perspektywie - tej, którą wnoszą współczesne badania nad dwu- i wielojęzycznością (Ligara 2011: 175).

5.4. Problem wyboru języka twórczości to zagadnienie stosunkowo często podejmowane w światowej literaturze poświęconej bilingwizmowi i wielojęzyczności. I tak na przykład znany badacz tej problematyki, François Grosjean (1989), podaje zestawienie powszechnie znanych osób, które były lub są dwujęzyczne. Na przygotowanej przez niego liście znajdujemy kilka osób posługujących się językiem polskim: wśród 
polityków Menachema Begina, znającego polski, hebrajski i angielski; wśród dostojników religijnych - Jana Pawła II, znającego polski, łacinę, włoski, niemiecki i angielski; wśród naukowców - Marię Curie, znającą polski i francuski (zapewne także rosyjski); wśród pisarzy - Josepha Conrada, znającego polski, francuski i angielski, oraz Czesława Miłosza, znającego polski, rosyjski, francuski i angielski; wśród muzyków - Fryderyka Chopina, znającego polski i francuski, oraz Artura Rubinsteina, znającego polski, francuski i angielski (Grosjean 1989: 51).

Stosunkowo dużo miejsca Grosjean poświęca Josephowi Conradowi, który zdobył światową sławę, tworząc literaturę w trzecim ze znanych sobie języków. Francuski badacz zwraca uwagę na polskie pochodzenie pisarza i na fakt, że Conrad mieszkał w Polsce przez 16 lat, gdzie poznał też podstawy francuskiego. Po wyjeździe do Francji mieszkał w tym kraju przez cztery lata, stając się osobą dwujęzyczną, znającą francuski równie dobrze jak polski. Mając 20 lat, Conrad zaczął pracować jako marynarz na brytyjskich statkach handlowych, gdzie zaczął się uczyć angielskiego. Karierę marynarza skończył w wieku 35 lat, już jako autor kilku publikacji literackich. Grosjean przypomina, że za życia Conrad był krytykowany z dwu stron: przez Anglików za to, że jest Polakiem udającym Anglika, oraz przez Polaków, że jest Anglikiem udającym Polaka, że nie nauczył swego syna polszczyzny itd. Podkreślając fakt tworzenia literatury w trzecim języku, a nie na przykład w drugim, francuskim, w którym pisał biegle, Grosjean stwierdza, że proza pisana przez Conrada prawie nie wymagała redakcji, natomiast jego wymowa nie była doskonała, gdyż do końca życia zachował obcy akcent, z czego zdawał sobie sprawę. Za Karlem przytacza następującą wypowiedź Conrada, wygłoszoną 20 lat po osiedleniu się Conrada w Anglii:

My pronunciation (in English) is rather defective to this day. Having unluckily no ear, my accentuation is uncertain, especially when in course of a conversation I become self-conscious. In writing I wrestle painfully with that language which I feel I do not possess but which possesses me - alas (ibid.: 53).

Ostatnie zdanie tej wypowiedzi Conrada wydaje się kluczem do wyboru języka angielskiego na język, w którym pisał: „Pisząc, zmagam się boleśnie z tym językiem, którego, jak czuję, nie posiadam, ale który, niestety, posiada mnie”. Grosjean dodaje, że Conrad do końca życia władał biegle polskim i francuskim, a w domu często używał trzech znanych sobie języków. W dodatku pisarz udzielał rad tłumaczom swoich dzieł na polski i francuski.

Analizując dwujęzyczność pisarzy, Grosjean stwierdza na koniec, że są znani autorzy tworzący w dwu językach (ibid.: 52-54). Pierwszym z nich jest Irlandczyk, Samuel Beckett, którego językiem ojczystym był angielski. Mimo że francuskiego nauczył się w szkole, a od 1937 r. mieszkał w Paryżu, Beckett początkowo pisał tylko po angielsku. Dopiero po wojnie, w czasie której walczył we francuskim ruchu oporu, zaczął pisać po francusku, a jego pierwszą nowelą w tym języku była Molloy, 
opublikowana w 1951 r. W 1969 r. Beckett został laureatem Nagrody Nobla za swe dzieła literackie tworzone w dwu językach.

Drugim pisarzem tworzącym w dwu językach jest Vladimir Nabokov, urodzony w Petersburgu w 1899 r. i wychowywany dwujęzycznie: po rosyjsku i francusku. Po rewolucji jego arystokratyczna rodzina opuściła ZSRR, co umożliwiło mu podjęcie studiów w znanych uczelniach. Angielski poznał bardzo dobrze, studiując w Trinity College w Dublinie oraz na Uniwersytecie Cambridge. Początkowo tworzył po rosyjsku, a tłumaczenia jego powieści zyskały uznanie na świecie. Wtedy zaczął pisać także po angielsku, publikując w tym języku powieści tak sławne jak np. Lolita. Nabokov wykorzystywał biegłą znajomość dwu języków, tłumacząc pisarzy rosyjskich na angielski i angielskich na rosyjski.

5.5. Przypomniany przez Grosjeana brak akceptacji Conrada jako cudzoziemca piszącego po angielsku zwraca uwagę na fakt, że dwujęzyczny pisarz zmaga się najpierw z językiem, w którym pisze, a na którego kształt wpływają inne znane mu języki, potem także ze społecznym odbiorem swej twórczości. Ważne jest to, że społeczny odbiór dzieł tworzonych przez pisarzy dwujęzycznych, należących na przykład do mniejszości narodowej żyjącej w danym kraju, może być w dużym stopniu kształtowany przez stereotypy i uprzedzenia na temat tej mniejszości, funkcjonujące w tym kraju. Klasycznym przykładem tego problemu są losy twórczości pisarzy żydowskich publikujących swe dzieła w języku polskim, w tym poety tak znakomitego jak Julian Tuwim, który polszczyznę chciał uczynić ojczyzną wszystkich mówiących po polsku. To właśnie on w tomiku Treść gorejąca z 1936 r. w wierszu Zieleń użył wyrażenia ojczyzna-polszczyzna.

Przypominamy tu, że autorem wyrażenia ojczyzna-polszczyzna jest Żyd, którego wiersz Zieleń został wydany w ostatnich latach okresu międzywojennego, kiedy jego autor był przedmiotem ciągłych ataków politycznych i prawdziwej nagonki

[...] prowadzonej przez prasę skrajnie prawicową, której znaczenie w procesie postępującej faszyzacji wzrastało nieustannie. [...] W napaściach owych lansowano tezę, że Tuwim nie jest poetą polskim, ale Żydem, który przypadkowo tylko pisze w języku polskim, psując go i wnosząc tzw. obce akcenty. Nagonka owa, prowadzona w najniewybredniejszy sposób przez takie pisma, jak „Prosto z Mostu”, „ABC”, „Falanga” i in., stała się jednym z najtragiczniejszych momentów w życiu Tuwima w okresie poprzedzającym wojnę. Dołączyło się do niej odejście wielu dawnych przyjaciół z kręgów sanacji (Głowiński 1986: VII-VIII; zob. też Urbanek 2004: 77-80).

W czasie wojny spędzonej poza Polską Tuwim opublikował w 1944 r. w wydawanej w Londynie Nowej Polsce manifest My, Żydzi polscy, w którym z jednej strony podkreślał swój związek i solidarność z narodem żydowskim, z drugiej zaś stwierdzał zaczepnie: Jestem Polakiem, bo mi się tak podoba. Oto jak uzasadniał swą decyzję o podjęciu twórczości poetyckiej w języku polskim: 
Polak, bo mi tak w domu rodzicielskim po polsku powiedziano; bo mnie tam polską mową od niemowlęcia karmiono; bo mnie matka uczyła polskich wierszy i piosenek; bo gdy przyszedł pierwszy wstrząs poezji, to wyładował się polskimi słowami; bo to, co w życiu stało się najważniejsze - twórczość poetycka - jest nie do pomyślenia w żadnym innym języku, choćbym nim jak najlepiej mówił (Urbanek 2004: 142, 144).

Nie ulega wątpliwości, że w przytoczonym fragmencie Tuwim mówi o języku polskim tak, jak powinien mówić każdy rodzimy użytkownik języka. O tym, czy jest się rodzimym użytkownikiem języka, czy też nie, nie decyduje bowiem pochodzenie etniczne mówiącego, ale jego znajomość języka i kultury polskiej, kultury przyswojonej i uznanej za własną, którą Antonina Kłoskowska (2005: 112) nazywa walencją kulturową. I język, i kulturę Tuwim przyswoił sobie znakomicie. Język i kulturę polską uznał za własne, poświęcając całe życie na tworzenie dzieł w języku polskim i rozwój polskiej kultury.

5.6. Na specjalną uwagę zasługują poglądy nacjonalistycznej prawicy polskiej, która tępiła kiedyś, ale i dziś w zasadzie nie akceptuje pisarzy niepolskiego pochodzenia. Zasługują na krytyczną uwagę, gdyż przedstawiciele wielkich narodów zwykle są dumni, że pisarze obcego pochodzenia wybrali ich język na narzędzie twórczości literackiej, że w ich języku tworzą swe dzieła. Fakt, że twórcy obcego pochodzenia piszą w języku jakiegoś narodu, świadczy o wielkości danego narodu i mocy jego języka, potwierdza zdolność przyciągania obcych do danego języka i kultury. Dlatego walcząc o wymyśloną przez siebie „czystość” języka, członkowie nacjonalistycznej prawicy chcą ograniczyć do niego dostęp, chcą w rzeczywistości zmniejszyć jego moc oddziaływania. Działając tak, działają w rzeczywistości na szkodę, a nie na korzyść języka.

\section{Inne prace na temat dwu-i wielojęzyczności}

6.1. Poprzednio była mowa o zainteresowaniu badaniem bilingwizmu po roku 200o, czemu jednak towarzyszyła uwaga, że znajduja się one poza głównym nurtem zainteresowań polskiej lingwistyki. Najwyraźniej jednak popularność badań zjawiska dwujęzyczności narasta, o czym zdają się świadczyć tomy nawiązujące w tytule do zjawiska wielojęzyczności. Pierwszym z nich jest tom Wielojęzyczność. Kontakty językowe w rozwoju kultur słowiańskich (Dubisz, Stąpor 2008). Jest on rezultatem prac Komisji Literackich Języków Słowiańskich, działającej przy Międzynarodowym Komitecie Slawistów. Prace zamieszczone w tomie zostały zgrupowane w trzech działach: pierwszy z nich dotyczy zagadnień ogólnych związanych z wielojęzycznością, kontaktami językowymi i zjawiskiem interferencji, drugi - kontaktów językowych na obszarze Słowiańszczyzny południowej, trzeci zaś - kontaktów językowych 
na terenie Słowiańszczyzny północnej, w którym dominują prace na temat kontaktów polszczyzny z takimi językami jak rosyjski, niemiecki, francuski, angielski i łacina. Wśród nich znajdujemy także prace mówiące o dwujęzyczności łużycko-niemieckiej i jej wpływie na kształtowanie się górnołużyckiego języka literackiego oraz o wielojęzyczności w Księstwie Cieszyńskim. To ostatnie studium Grenia przynosi wnikliwą analizę językowego materiału historycznego od XV w., która pozwala autorowi mówić o dwujęzyczności słowiańsko-niemieckiej, a po uwzględnieniu rozdziału czeszczyzny i polszczyzny o trójjęzyczności polsko-czesko-niemieckiej. Zastanawiając się nad rozdziałem funkcjonalnym języków czeskiego i polskiego, badacz dochodzi do następującego wniosku:

[...] w zakresie języka pisanego, języka dokumentów, była to z pewnością kompetencja czeska (w odmianie morawskiej). Wynikało to z prostego faktu administracyjnego - przynależności (lennej) do Korony Czeskiej. Już jednak problem standardu oficjalnego mówionego (języka dworu książęcego, dworów szlacheckich) jest otwarty. Natomiast język nieoficjalny, domowy, w dużej mierze był obsługiwany przez regionalną odmianę polszczyzny (a w niższych warstwach społecznych przez polskie gwary) (Greń 2008: 257-258).

Jak widać, wielojęzyczność Śląska Cieszyńskiego ma charakter zróżnicowany, gdyż przy jej opisie należy uwzględnić zarówno zjawisko dyglosji, jak też czynną lub bierną znajomość poszczególnych języków (por. 3.3.; 3.4.).

6.2. Ciekawym uzupełnieniem badań Grenia z roku 2000 jest zbiór pięciu prac wydany pod redakcją Jiřiego Muryca (2012). Autorzy prac zajęli się językami tworzącymi dyskurs religijny w czeskiej części Śląska Cieszyńskiego, badając sytuację panującą w dwu kościołach: rzymsko-katolickim i w Śląskim Kościele Ewangelickim wyznania augsburskiego. Redaktor tomu podkreśla, że problematyka dyskursu religijnego znajdowała się dotychczas na peryferiach zainteresowania badaczy i jeśli była poruszana, to zwykle powierzchownie. Dlatego autorzy prac zajęli się najpierw historią życia religijnego na czeskim Śląsku Cieszyńskim, potem polszczyzną w źródłach historycznych z XVIII w., z kolei - aktualną sytuacją językową w badanych kościołach, interferencjami $\mathrm{w}$ wypowiedziach duchownych odprawiających nabożeństwa w kościołach, wreszcie - językiem pisanym periodyków religijnych. Zdając sobie sprawę ze specyfiki tematyki badawczej, Muryc stwierdza jednak, że

[...] temat dyskursu religijnego przekracza granice swojego odosobnienia [i] ma wpływ na całą społeczność [...] Zagadnienia dotyczące wiary, podobnie jak i szkolnictwa, kultury czy tradycji są ważnym wyznacznikiem narodowej i regionalnej przynależności (Muryc 2012: 107),

z czym trudno się nie zgodzić. 
6.3. Innym tomem, o którym warto wspomnieć, jest monografia glottodydaktyczna Ewy Domagały-Zyśk (2013). Autorka szczegółowo analizuje w niej proces uczenia się języka angielskiego jako obcego przez studentów niesłyszących i słabosłyszących, używających języka migowego oraz polszczyzny, i w tym sensie wielojęzycznych. Przy okazji warto wspomnieć, że Domagała-Zyśk nie jest pierwszą autorką traktującą język migowy jako język pierwszy posługujących się nim. Wcześniej Marta Korendo (2009) traktowała uczniów niesłyszących jak osoby dwujęzyczne, posługujące się dwoma językami: językiem migowym i polskim. Polszczyzna literacka jest jej zdaniem językiem drugim dzieci niesłyszących. Kłopoty w opanowaniu języka polskiego Korendo tłumaczyła konsekwentnie interferencjami z języka migowego, dochodząc do wniosku, że niestyszący tak pisza (mówią), jak migają (Korendo 2009: 155).

6.4. Na marginesie uwag o wzroście zainteresowania badaniem zjawiska dwu-i wielojęzyczności interesująca może być informacja, jak wygląda zainteresowanie problematyką języka polskiego w świecie, szczególnie jednak bilingwizmu polsko-obcego wśród studentów studiów magisterskich specjalności Nauczanie języka polskiego jako obcego i drugiego, prowadzonych przez Katedrę Języka Polskiego jako Obcego UJ. Uczestnicy tych dwuletnich studiów magisterskich piszą prace magisterskie, które mogą dotyczyć dydaktyki polszczyzny jako języka obcego i drugiego, polszczyzny używanej poza Polską, w tym dwujęzyczności członków zbiorowości polonijnych i polskich, wreszcie - literatury i kultury w nauczaniu cudzoziemców, a także gramatyki porównawczej i tłumaczenia tekstów. Studia te ruszyły w 2005 r. i dlatego pierwsze prace magisterskie zostały ukończone w $2007 \mathrm{r}$. W okresie od czerwca 2007 do lipca 2013 r. powstało 115 prac, spośród których ponad 50\% dotyczyło różnych zagadnień dydaktyki polszczyzny jako języka obcego i drugiego, 26\% gramatyki porównawczej i tłumaczenia, a $24 \%$ języka polskiego poza Polską oraz bilingwizmu grupowego i indywidualnego, przy czym w tej ostatniej grupie aż połowa tematów (14 prac) była związana z badaniem bilingwizmu indywidualnego. Niektóre z tych prac, uznane za wyróżniające się, zostały opublikowane w postaci artykułów, na przykład praca Marty Guillermo-Sajdak o psychologicznych aspektach wielojęzyczności hiszpańsko-francusko-angielsko-polskiej (2009), studium Karoliny Kowalcze na temat wyrażania emocji przez osoby dwujęzyczne polsko-włoskie (2009) czy praca Katarzyny Dzierżawin o bilingwizmie polsko-ukraińskim młodzieży uczącej się w Przemyślu (2009).

\section{Metodologia badań nad dwujęzycznością a nowe kierunki w badaniach lingwistycznych}

7.1. Badania bilingwizmu polsko-obcego należy odnieść także do dokonujących się stopniowo na świecie i w Polsce zmian w metodologii badań lingwistycznych. Zmiany te widać w omawianych dotąd pracach, ale najczęściej dzieje się tak, że ich 
autorzy poszerzają metodologię stosowaną dotąd w badaniach lingwistycznych kontaktów językowych, w badaniach socjolingwistycznych, pedagogicznych czy rzadziej - psycholingwistycznych o nowe metody, nie zawsze deklarując stosowanie innej metodologii. Widać to jednak w tytułach takich opracowań jak Bilingwizm polsko-portugalski w Brazylii. W stronę lingwistyki humanistycznej Miodunki (2003), Dwujęzyczność i dwukulturowość w perspektywie psychopedagogicznej Czykwin i Misiejuk (2002), Język - tożsamość - imigracja. O strategiach adaptacyjnych Polaków zamieszkatych we Francji w latach osiemdziesiątych XX wieku Wróblewskiej-Pawlak (2004), Dwujęzyczność, dwukulturowość - przekleństwo czy bogactwo? O poszukiwaniu tożsamości Polaków w Austrii Cieszyńskiej (2006), Dziecko w środowisku dwujęzycznym i jego komunikacja międzykulturowa Kainacher (2007), Bilingwizm polsko-francuski Adama Mickiewicza. W stronę antropologii lingwistycznej Ligary (2010), Dwujęzyczność, walencja kulturowa i tożsamość (e)migracji polskiej w świecie Miodunki (2010), Dwujęzyczność i ponglish. Zjawiska językowo-kulturowe polskiej emigracji w Wielkiej Brytanii Błasiak (2011; podkr. - W.M.). Już z tego zestawienia tytułów omawianych prac widać, że najczęściej pojawiają się w nich pojęcia 'język', 'dwujęzyczność,' 'kultura,' 'dwukulturowość', 'komunikacja międzykulturowa' i 'tożsamość', a w kilku przypadkach znajdujemy wręcz odwołania do kierunków badań w lingwistyce: do lingwistyki humanistycznej i antropologii lingwistycznej. Dlatego warto tu zastanowić się nad powiązaniami badań bilingwizmu z nurtem antropologiczno-kulturowym w polskim językoznawstwie, o którym pisała Elżbieta Sękowska (2000), wyróżniając w nim lingwistykę kulturową, lingwistykę antropologiczną i antropologię lingwistyczną.

Lingwistyka kulturowa bada relacje między językiem, kulturą, człowiekiem (społeczeństwem) a rzeczywistością pozajęzykową, główny nacisk kładąc jednak na relacje między językiem a kulturą, gdzie znajdujemy takie tematy szczegółowe jak

[...] kulturowe i kulturotwórcze funkcje języka i tekstów językowych, kategorie gramatyczne, semantyczne, pragmatyczne i ich kulturowe ujęcie, kulturowe aspekty kategorii badawczej językowy obraz świata, etykieta językowa odniesiona do danego języka narodowego i do języków grup społecznych (Sękowska 2000: 12).

Podobnymi komponentami zajmuje się lingwistyka antropologiczna, zwana w Polsce także etnolingwistyką, jednakże inaczej ujmuje ona ich hierarchię, na pierwszym miejscu stawiając relacje między językiem a człowiekiem (społeczeństwem), w dalszej perspektywie odnosząc się do relacji tych dwu elementów w stosunku do rzeczywistości pozajęzykowej i kultury.

W tym ujęciu lingwistyka antropologiczna jest nauką o człowieku widzianym przez pryzmat języka, człowieku, którego tworem jest język i którego obraz jest zawarty w języku. Nauka ta dąży do zrozumienia wszystkiego, co dotyczy człowieka - jego rozwoju jako istoty społecznej oraz jego zachowań i wytworów kulturowych (ibid.). 
Antropologia lingwistyczna bada związki między kulturą, językiem i danym społeczeństwem, poszukując

[...] wzorów działania charakterystycznych dla danego społeczeństwa, przejawiających się w obrzędach, legendach, mitach oraz typowych regułach językowych (ibid.: 13).

7.2. Ogólne ustalenia Sękowskiej warto odnieść do konkretnych propozycji badawczych, przedstawionych przez twórcę etnolingwistyki polskiej, Jerzego Bartmińskiego. W swej książce Językowe podstawy obrazu świata przedstawia on między innymi minimalny program badania językowego obrazu świata, w którym zwraca uwagę na sześć problemów badawczych: 1) badanie autostereotypów, związane z odpowiedzią na pytanie Kim jesteśmy „my”?; 2) badanie heterostereotypów, odpowiadających na pytanie Kim sq „oni”?; 3) opis konceptualizacji przestrzeni i „naszego" miejsca w świecie; 4) analizę konceptualizacji czasu wspólnotowego, w którym przyszło nam żyć; 5) analizę systemu wartości funkcjonujących w „naszym” społeczeństwie; 6) opis językowych środków wyrazu, czyli typów wypowiedzi z wyróżnieniem stylów i gatunków (Bartmiński 2007: 19-21).

W tym interesującym programie badań warto zwrócić specjalną uwagę na dwa pierwsze problemy i pytania badawcze, biorąc pod uwagę badania dwu- i wielojęzyczności, zarówno indywidualnej, jak też zbiorowej. Otóż pytania Kim jestem? Kim jesteśmy? to w badaniach socjologicznych i psychologicznych tradycyjne pytania o tożsamość najpierw indywidualną, potem zbiorową, przejęte później w badaniach lingwistycznych. Jak zwracaliśmy uwagę, badacze dwujęzyczności często stawiają pytanie o tożsamość badanych, którzy mogą ją wiązać z językiem i kulturą pierwszą (ojczystą), ale też z językiem i kulturą drugą (obcą). Ponieważ pytanie o tożsamość jest często postrzegane jako pytanie o rozstrzygnięcie, oczekujemy na nie krótkiej, zwykle jednowyrazowej odpowiedzi (np. (Jestem) Polakiem; Brazylijczykiem; Niemcem itd.). Inaczej rzecz się ma z pytaniem o stereotyp: w odpowiedzi na nie oczekujemy zbioru cech opisujących jakąś grupę społeczną (np. naród). Dlatego bardziej precyzyjne w tym przypadku byłoby pytanie Jacy jesteśmy?

Pytanie o tożsamość jest proste językowo, ale odpowiedź na nie bywa (bardzo) skomplikowana, jeśli odpowiadający musi wziąć pod uwagę autostereotyp grupy, do której dotąd się zaliczał (zaliczali go rodzice czy zaliczali go inni), jak też heterostereotyp grupy, do której chciałby się zaliczać (chciałby być zaliczany). Nie tak rzadko bowiem zdarza się, że to, jak postrzega się sam mówiący, różni się od tego, jak postrzegają go inni. O procesie zmiany tożsamości pisała bardzo interesująco Kłoskowska (2005), uważając konwersje narodowe za zjawisko pogranicza. W przypadku emigracji polskiej i Polonii zwracała ona uwagę na różne natężenie polskości u poszczególnych osób i grup, na tzw. skali polskości (ibid.: 389-413). Z punktu widzenia językoznawczego proces ten opisywali np. Miodunka (1990a, 2003), Wróblewska-Pawlak (2004), Laskowski (2013). Nie ulega wątpliwości, że kształtowanie się i zmiana stereotypów 
jest procesem, podobnie jak kształtowanie się i zmiana tożsamości. Różnica polega na tym, że na zmianę stereotypu potrzeba znacznie więcej czasu niż na zmianę tożsamości, zwłaszcza indywidualnej.

7.3. Nurt antropologiczno-kulturowy, o którym pisała Sękowska (2000), nabiera siły i znaczenia, o czym zdaje się świadczyć między innymi publikacja monografii Piotra Chruszczewskiego (2011). We wstępie do niej Jacek Fisiak stwierdza, że językoznawstwo antropologiczne jest w świecie młodą dyscypliną naukową, w Polsce zaś jest „w zasadzie nieobecne”. Z tego względu uważa on pracę Chruszczewskiego za „jeden z pionierskich kroków w kierunku emancypacji językoznawstwa antropologicznego w polskich instytucjach naukowych" (Chruszczewski 2011: 11). Pierwsze stwierdzenie Fisiaka trzeba zapewne skorygować, biorąc pod uwagę fakt, iż prace składające się na nurt antropologiczno-kulturowy ukazują się w naszym kraju od początku lat 9o. wieku XX. Natomiast $\mathrm{z}$ drugim trzeba się zgodzić, ponieważ językoznawstwu antropologicznemu brakowało dotąd pracy w pewnym sensie programowej, prezentującej ten kierunek badań i jego możliwości, a taką pracą jest monografia Chruszczewskiego.

W podsumowaniu tej monografii autor wyróżnia za Durantim cztery paradygmaty językoznawstwa antropologicznego: dokumentacyjny, kulturowo-lingwistyczny, transformacyjny i komunikacyjno-dyskursywny. Zadaniem pierwszego z nich jest opis i klasyfikacja języków rdzennych na poszczególnych kontynentach, podczas gdy w ramach drugiego prowadzi się badania „użycia języka wśród ludzi i czynności, jakie wykonują”, rozumiejąc sam język jako „domenę kulturowo zorganizowaną i organizującą kulturę". Paradygmat transformacyjny polega na „dokumentacji i analizie sposobów odtwarzania i transformacji instytucji i grup społecznych w przestrzeni i czasie" przy pomocy praktyk językowych. Ostatni z paradygmatów, komunikacyjno-dyskursywny, stawia sobie za cel „opis, dokumentację i analizę zmian językowo-społeczno-kulturowych w czasie i przestrzeni” (ibid.: 264-271).

$\mathrm{W}$ prowadzonych dotąd badaniach dwujęzyczności odnajdujemy wątki i zagadnienia teoretyczne z dwu paradygmatów: kulturowo-lingwistycznego oraz transformacyjnego, takie jak zmiana języka i zmiana językowa, mechanizmy i modele tych zmian, wzajemne relacje języka oraz kontekstu społecznego i kulturowego, mechanizmy pamiętania i zapominania języka (rzadko używanego), kształtowanie się i przemiany tożsamości.

7.4. Najmniej dotychczas napisano na temat lingwistyki humanistycznej, jej teorii i praktyki badawczej, choć istnieją prace, których autorzy tak właśnie nazywają swoją orientację naukową w ramach lingwistyki (np. Miodunka 2003; Cieszyńska 2006; Korendo 2009). Nie ulega wątpliwości, że lingwistyka humanistyczna odwołuje się do tych samych elementów co lingwistyka kulturowa i antropologiczna, inaczej jednak postrzega relacje między nimi. Spośród czterech powtarzających się elementów języka, kultury, człowieka (społeczeństwa) i rzeczywistości - na pierwszym miejscu stawia ona człowieka rozumianego jako osobę ludzką w ujęciu Viktora Frankla (2010). 
Człowiek ma tu szczególnie bliskie związki z językiem, który jest postrzegany nie tylko jako narzędzie jego komunikacji z innymi ludźmi, ale także jako niezbędne narzędzie samorealizacji. Można powiedzieć, że język staje się elementem konstytutywnym bycia człowiekiem, bezpośrednio warunkującym funkcjonowanie każdej osoby w społeczeństwie. Lingwistyka humanistyczna nie tylko analizuje relacje między człowiekiem a językiem, ale także zwraca uwagę na deficyty językowe człowieka: od zaburzeń rozwoju mowy, którymi zajmuje się logopedia, aż po deficyty językowe poszczególnych osób, których poziom rozwoju językowego (kompetencji językowej) nie odpowiada odgrywanej roli społecznej. Podobnie jak logopedia nie tylko opisuje zaburzenia, ale także proponuje ich terapię, tak lingwistyka humanistyczna powinna wpływać na rozwiązania edukacyjne w celu usuwania deficytów językowych widocznych we współczesnym społeczeństwie polskim.

7.4.1. Z tych względów lingwistyka humanistyczna za tak samo istotne uważa badanie rozwoju i funkcjonowania językowego jednostki ludzkiej, jak i całej grupy społecznej. To różni ją zasadniczo od lingwistyki kulturowej w rozumieniu Anusiewicza (1995), etnolingwistyki w rozumieniu Bartmińskiego (2007) czy lingwistyki antropologicznej w rozumieniu Chruszczewskiego (2011). Nadawanie tej samej rangi badaniom funkcjonowania językowego jednostki i grupy społecznej widać dobrze w badaniach dwujęzyczności, gdzie tak samo ceni się studia przypadków dwujęzyczności indywidualnej, jak i analizy dwujęzyczności grupowej, a dwujęzyczność grupowa często jest ilustrowana przykładami dwujęzyczności indywidualnej (por. Miodunka 2003; Wróblewska-Pawlak 2004; Cieszyńska 2006; Dębski 2009). Podobną praktykę badawczą spotykamy w opisie i terapii zaburzeń języka, czyli w logopedii, gdzie terapia jest najczęściej indywidualna, ale terapeuta musi korzystać z ogólnej wiedzy na temat konkretnego zaburzenia, powstałej w wyniku kumulacji opisów indywidualnych. W metodologii badań polega to na opisie funkcjonowania językowego danej grupy społecznej, które powinno być zilustrowane opisem funkcjonowania jednostek, przedstawiających sobą poszczególne typy.

7.4.2. Narzędzie komunikacji społecznej, jakim jest język, informuje nas o rzeczywistości pozajęzykowej, ale informuje nas także o emocjach i uczuciach nas samych oraz innych ludzi. Biorąc to pod uwagę, lingwistyka humanistyczna zwraca uwage na ładunek emocjonalny poszczególnych przekazów i całej komunikacji językowej. Ładunek ten ułatwia przekazywanie poszczególnych znaczeń oraz komunikację globalną, ale ma szczególne znaczenie w okresie socjalizacji pierwotnej, w trakcie której dziecko nabywa język: dziecko akceptowane i kochane łatwiej uczy się języka, łatwiej rozwija swój język czy poddaje się terapii, mającej na celu usunięcie konkretnego zaburzenia. To dlatego zaleca się rodzinom na emigracji, by rodzice mówili do swych dzieci w języku etnicznym, w którym umieją wyrazić wszystkie swoje emocje i uczucia, a nie w języku kraju osiedlenia, który znają zbyt słabo, żeby je odpowiednio wyrazić. 
Biorąc pod uwagę fakt, że swoboda przemieszczania się ludzi w UE stawia przed wszystkimi zainteresowanymi wyzwanie stawania się (bycia) dwu- lub wielojęzycznymi, lingwistyka humanistyczna podkreśla, że każdy język może i powinien być narzędziem samorealizacji osoby ludzkiej, pod warunkiem że jest odpowiednio rozwinięty funkcjonalnie.

\section{Perspektywy badań dwu-i wielojęzyczności}

8.1. W lingwistycznych badaniach dwujęzyczności można wyróżnić dwie warstwy: starszą, mieszczącą się w ramach badań kontaktów językowych, i nowszą, obejmującą badania roli języka w kształtowaniu się i przemianach tożsamości, związków między językami a walencją kulturową czy roli języka (języków) w procesie samorealizacji człowieka. Na podjęcie oczekują zagadnienia zmiany języka oraz mechanizmów i modeli zmian, mechanizmów pamiętania lub zapominania języka rzadziej (rzadko) używanego oraz wzajemnych relacji między językiem (językami) a kontekstem społecznym i kulturowym.

Nowa sytuacja powstała na wschód od Polski, np. na Ukrainie, Białorusi, w Rosji czy w Mołdawii, stwarza okazję do prowadzenia studiów nad procesem powrotu do języka polskiego lub nabywania jego znajomości w sytuacji wcześniejszej dwulub trójjęzyczności. Studia tam prowadzone powinny brać pod uwagę zagadnienie mocy polszczyzny oraz polskiej polityki językowej (Dąbrowska, Miodunka, Pawłowski 2012).

8.2. Nie oznacza to, że badania kontaktów językowych są wyczerpane, gdyż obecnie znamy rejestr zjawisk zwykle tu występujących (np. przełączanie kodów, mieszanie kodów, interferencje leksykalne i składniowe, kalki wyrażeń frazeologicznych itp.), natomiast nie wiemy, czy ich występowanie w mowie osób dwujęzycznych jest przypadkowe, czy też podlega prawidłowościom i pełni określone funkcje. Wydaje się, że należy przyjąć raczej tę drugą możliwość i ustalić prawidłowości oraz funkcje tych zjawisk w wyniku analizy mowy osób dwu- lub wielojęzycznych oraz tekstów tworzonych przez te osoby.

8.3. Należy uznać, że badania zachowania i przemian języka polskiego poza Polską zostały podsumowane w (Dubisz 1997a). Na uwagę zasługuje zawarte w tym tomie opracowanie Dubisza Język polski poza granicami kraju - próba charakterystyki kontrastowej (1997b: 324-371), w którym autor postuluje

[...] rejestrację kontrastów językowych wobec dwóch podstaw porównawczych, tj. języka polskiego w kraju (w jego zróżnicowaniu wariantowym) i języka kraju osiedlenia zbiorowości polonijnej lub autochtonicznej polskiej grupy etnicznej czy skupiska osadniczego (przesiedleńczego) (ibid.: 325). 
Koncentrując się na opisie interferencji językowych, Dubisz mówi w nim między innymi o „czynnym bilingwizmie części członków zbiorowości polonocentrycznych”. Dlatego tom ten trzeba postrzegać jako z jednej strony podsumowanie badań kontaktów językowych polszczyzny z innymi językami, z drugiej zaś - jako zapowiedź badań dwujęzyczności.

Dokonując 13 lat później bilansu badań języka emigracji polskiej w świecie, Sękowska poświęca pierwszą część rozdziału drugiego na omówienie zjawiska bilingwizmu, kontaktów językowych i interferencji (Sękowska 2010: 33-56). Z kolei pisząc o perspektywach badawczych, na pierwszym miejscu stawia analizę

[...] skryptów kulturowych, czyli wzorów językowych zachowań, wpływających na kształt i dynamikę komunikacji. Odmienne kultury posługują się zróżnicowanymi skryptami kulturowymi, co w wielu pracach udowodniła Anna Wierzbicka. Nieznajomość skryptów naraża uczestnika komunikacji na niepowodzenia i prowadzi do konfliktów (ibid.: 106).

8.4. Za bardzo ważne należy uznać badania dwu- i wielojęzyczności indywidualnej zarówno twórców literatury polskiej, jak i innych osób dwujęzycznych. Ponieważ aktualnie przyjmuje się, że osoba dwujęzyczna dysponuje nie tyle dwoma odseparowanymi od siebie systemami językowymi, co dwoma językami wzajemnie wpływającymi na siebie, w analizie języka należy uwzględniać przekraczanie granicy normy językowej, zaobserwowane przez Ligarę (zob. 5.2.-5.3.). Unieważnia to stosowany czasami opis języka polskiego osób dwujęzycznych jako polszczyzny deficytowej, kiedy deficyty ustala się w wyniku porównania z polszczyzną osób monolingwalnych w kraju, co nie wydaje się w tej sytuacji uprawnione.

Badania języka listów romantyków polskich w Paryżu zwracają uwagę na konieczność innego spojrzenia na zależności między językiem (językami) a grupami społecznymi. Dotąd pisarze romantyczni byli postrzegani jako wybitni członkowie narodu polskiego, na emigracji walczący o polskość przy pomocy dzieł literackich. Teraz widzimy ich również jako członków dwujęzycznej społeczności emigracyjnej w Paryżu, odgrywających tam różne role społeczne i w zależności od nich posługujących się na przemian językiem polskim albo językiem francuskim lub oboma językami w tym samym akcie komunikacji. Taka wizja, dla niektórych zaskakująca czy wręcz szokująca, jest jednak bliższa prawdzie, pokazując różne oblicza pisarza emigracyjnego.

\section{Literatura}

BARTMIŃsKI J., 2007, Językowe podstawy obrazu świata, Lublin.

BŁASIAK M., 2011, Dwujęzyczność i ponglish. Zjawiska językowo-kulturowe polskiej emigracji $w$ Wielkiej Brytanii, Kraków.

Borawski S., 2000, Wprowadzenie do historii języka polskiego. Zagadnienia historiozoficzne, Warszawa. 
Brzezina M., 1986, Polszczyzna Żydów, Warszawa-Kraków.

Brzezina M., 1989, Polszczyzna Niemców, Warszawa-Kraków.

Chruszczewski P.P., 2011, Językoznawstwo antropologiczne. Zadania i metody, Wrocław.

Cieszyńska J., 2006, Dwujęzyczność, dwukulturowość - przekleństwo czy bogactwo? O poszukiwaniu tożsamości Polaków w Austrii, Kraków.

Cockiewicz W., 2013, Jak uporzadkować terminologiczny chaos w glottodydaktyce i po co?, „LingVaria” VIII, nr 1, s. 201-213.

Czy кwin E., Misiejuk D., 2002, Dwujęzyczność i dwukulturowość w perspektywie psychopedagogicznej, Białystok.

Dąbrowska A., Miodunka W., Pawıowski A., 2012, Wyzwania polskiej polityki językowej za granica: kontekst, cele, środki i grupy odbiorcze, Warszawa.

DęBSKi R., 2009, Dwujęzyczność angielsko-polska w Australii. Języki mniejszościowe w dobie globalizacji i informatyzacji, Kraków.

DomagaŁA-Zyśk E., 2013, Wielojęzyczni. Studenci niesłyszący i słabosłyszacy w procesie uczenia się i nauczania języków obcych, Lublin.

Dubisz S. (red.), 1997a, Język polski poza granicami kraju, Opole.

DuBISz S., 1997b, Język polski poza granicami kraju - próba charakterystyki kontrastowej, [w:] idem (red.), Język polski poza granicami kraju, Opole, s. 324-376.

Dubisz S., StąPor I. (red.), 2008, Wielojęzyczność. Kontakty językowe w rozwoju kultur słowiańskich, Pułtusk.

Dubisz S., 2009, Dzieje języka polskiego jako problem badawczy w pracy historyka języka, „Poradnik Językowy” z. 3, s. 19-34.

DzIERżAwin K., 2009, Bilingwizm polsko-ukraiński. Badania wśród ukraińskiej młodzieży uczącej się w Przemyślu, „Kijowskie Studia Polonistyczne”, Kijów.

EJO: K. Polański (red.), Encyklopedia językoznawstwa ogólnego, Wrocław 1999.

EJP: S. Urbańczyk (red.), Encyklopedia jezzyka polskiego, Wrocław 1994.

FRANKL V.E., 2010, Wola sensu. Założenia i zastosowanie logoterapii, Warszawa.

GŁowiŃski M., 1986, Wstęp, [w:] J. Tuwim, Wiersze wybrane, wyd. IV, BN I nr 184, Wrocław, s. VII-VIII.

Greń Z., 200o, Śląsk Cieszyński. Dziedzictwo językowe, Warszawa.

Greń Z., 2008, Wielojęzyczność w Wielkim Księstwie Cieszyńskim, [w:] S. Dubisz, I. Stąpor (red.), Wielojęzyczność. Kontakty językowe w rozwoju kultur słowiańskich, Pułtusk, s. 241-265.

Greń Z., 2012, Parametry socjolingwistyczne w badaniach językowych na pograniczu, [w:] H. Kurek (red.), Języki słowiańskie w ujęciu socjolingwistycznym, Kraków.

Grosjean F., 1989, The Bilingual as a Person, [w:] R. Titone (red.), On the Bilingual Person, Ottawa, s. 35-54.

Grucha£a J.S., Kurek H. (red.), 2010, Silva rerum philologicarum. Studia ofiarowane Profesor Marii Strycharskiej-Brzezinie z okazji Jej jubileuszu, Kraków.

Guillermo-Sajda M., 2009, Pomiędzy językami hiszpańskim, francuskim, angielskim i polskim. Psychologiczne aspekty wielojęzyczności, [w:] W.T. Miodunka (red.), Nowa generacja $w$ glottodydaktyce polonistycznej, Kraków, s. 17-48.

Harris R.Mcl., Smolicz J., 1984, Australijczycy polskiego pochodzenia. Studium adaptacji i asymilacji młodego pokolenia, Wrocław.

JAковSON R., 1989, Wspólny język lingwistów i antropologów, [w:] idem, W poszukiwaniu istoty języka. Wybór pism, M.R. Mayenowa (red.), t. I, Warszawa, s. 471-489. 
KAINACHER K., 2007, Dziecko w środowisku dwujęzycznym i jego komunikacja międzykulturowa, Kraków.

Kајтосн W., 1999, Języki mniejszości narodowych w Polsce, [w:] W. Pisarek (red.), Polszczyzna 200o. Orędzie o stanie języka na przełomie tysiącleci, Kraków, s. 279-305.

KŁoskowsKa A., 2005, Kultury narodowe u korzeni, Warszawa.

Korendo M., 2009, Jak dzieci niesłyszące czytają teksty podręczników szkolnych?, Kraków.

Kowalcze K., 2009, Bilingwizm w sytuacji komunikacyjnej wyrażania emocji. Studium przypadków dwujęzyczności polsko-włoskiej, [w:] W.T. Miodunka (red.), Nowa generacja w glottodydaktyce polonistycznej, Kraków, s. 49-84.

LASKowski R., 2009, Język w zagrożeniu. Przyswajanie języka polskiego w warunkach polsko-szwedzkiego bilingwizmu, Kraków.

LAskowski R., 2013, Język a tożsamość etniczna. Kształtowanie się poczucia narodowego młodej polskiej diaspory w warunkach wielokulturowości, „LingVaria” VIII, nr 2, s. 77-93.

LigARA B., 1987, Galicyzmy leksykalne w listach Zygmunta Krasińskiego na tle wpływów francuskich w polszczyźnie XIX wieku. Studium bilingwizmu polsko-francuskiego, Kraków.

Ligara B., 2010, Bilingwizm polsko-francuski Adama Mickiewicza. W stronę antropologii lingwistycznej, „LingVaria” V, nr 2, s. 141-170.

Ligara B., 2011, Dwujęzyczność twórców literatury polskiej jako problem badawczy historii języka, „LingVaria” VI, nr 1, s. 165-178.

LipiŃsKa E., 2003, Język ojczysty, język obcy, język drugi. Wstęp do badań dwujęzyczności, Kraków.

Michalewska M.T., 1991, Polszczyzna osób bilingwalnych w Zagłębiu Ruhry w sytuacji oficjalnej, Kraków.

Miodunka W., 1990a, Język a identyfikacja kulturowa i etniczna. Studium kształtowania się tożsamości rodzeństwa należącego do drugiego pokolenia Polonii australijskiej, [w:] idem (red.), Język polski w świecie. Zbiór studiów, Warszawa-Kraków, s. 105-125.

Miodunka W. (red.), 199ob, Język polski w świecie. Zbiór studiów, Warszawa-Kraków.

Miodunka W.T., 2003, Bilingwizm polsko-portugalski w Brazylii. W stronę lingwistyki humanistycznej, Kraków.

Miodunka W.T., 2010a, Dwujęzyczność, walencja kulturowa i tożsamość (e)migracji polskiej $w$ świecie, „Biuletyn Polskiego Towarzystwa Językoznawczego” LXVI, s. 51-71.

Miodunka W.T., 2010b, O obecność w historii języka polskiego studiów nad polszczyzna mniejszości narodowych i grup etnicznych. Jubileusz prof. Marii Strycharskiej-Brzeziny, „LingVaria” V, nr 2, s. 267-277.

Miodunka W.T., 2011, Między etniczno-genealogicznym a kulturowym rozumieniem narodu. O potrzebie historycznojęzykowych badań polszczyzny jako języka obcego i drugiego, „LingVaria" VI, nr 1, s. 179-204.

Miodunka W.T., 2013a, Jakość polszczyzny używanej przez cudzoziemców. Metody analizy jakości na materiale egzaminów certyfikatowych z języka polskiego jako obcego w roku 2011, „Poradnik Językowy” z. 1, s. 53-68.

Miodunka W.T., 2013b, O definiowaniu języków ojczystego i obcego oraz o „terminologicznym chaosie” w glottodydaktyce - polemicznie, „LingVaria” VIII, nr 2, s. 275-283.

Muryc J. (red.), 2012, Církevní diskurz v širším společensko-historickém kontextu českého Těšínska, Ostrava.

Pisarek W. (red.), 1999, Polszczyzna 2000. Orędzie o stanie języka na przełomie tysiącleci, Kraków. 
Prieur J.-M., 2006, Des écrivains en contact de langues, „Études de Linguistique Appliquée” nr 144, s. 485-492.

ReCzeK J., 1989, Języki w dawnej Rzeczypospolitej, „Język Polski” z. 1-2, s. 19-28.

ReCZEK J., 1994, Języki w przedrozbiorowej Rzeczypospolitej, [w:] EJP, Wrocław, s. 139-146.

Schlottmann M., 1995, Wpływ czynników pozajęzykowych na nabywanie języka drugiego (niemieckiego) na przykładzie polskich emigrantów w Niemczech, „Przegląd Polonijny” XVIII, Z. 2, s. 41-57.

SĘKOWsKa E., 200o, Nurt antropologiczno-kulturowy we współczesnym polskim językoznawstwie, „Poradnik Językowy” z. 6, s. 11-20.

SŁ̨KOWsKa E., 2010, Język emigracji polskiej w świecie. Bilans i perspektywy badawcze, Kraków. SmuŁкowa E., 1990, Problematyka badawcza polsko-białorusko-litewskiego pogranicza językowego, [w:] J. Rieger (red.), Studia nad polszczyzną kresową, t. V, Warszawa, s. 151-164.

StrycharsKa-BrzezInA M., 2009, Socjostylistyka a dzieje literatury polskiej. Studia nad stylizacja językowa w utworach literackich, Kraków.

URBANEK M., 2004, Tuwim, Wrocław.

WARchoє-Schlottmann M., 1996, Język polski w Niemczech-perspektywy zachowania języka etnicznego u najnowszej emigracji, „Przegląd Polonijny” XXII, z. 3, s. 31-50.

WierzbickA A., 1990, Podwójne życie człowieka dwujęzycznego, [w:] W. Miodunka (red.), Język polski w świecie, Warszawa-Kraków, s. 71-104.

WróBlEWSKA-PAWLAK K., 2004, Język - tożsamość - imigracja. O strategiach adaptacyjnych Polaków zamieszkałych we Francji w latach osiemdziesiątych XX wieku, Warszawa.

Wyderka B., 2011, O konieczności nowej syntezy dziejów języków na Śląsku, [w:] B. Dunaj, M. Rak (red.), Badania historycznojęzykowe. Stan, metodologia, perspektywy, Kraków, s. $387-395$.

\section{Polish-foreign bilingualism in Poland and outside of it. Research development and perspectives Summary}

The paper summarizes research on Polish-foreign bilingualism in Poland and outside of its borders. It takes various works into account, regardless of whether their authors place bilingualism in the centre of their research interests, or only mention it in the background of considerations on the use of Polish in the given national or ethnic minority. Apart from works on modern Polish-foreign bilingualism, the author discusses research into bi- and multilingualism in Polish linguistic history. Particular attention is given to the Polish-French bilingualism of Polish romantic authors of the $19^{\text {th }}$ century. The final part of the paper reviews the methodology of research into bilingualism, especially those methods that extend beyond the analysis of linguistic contacts, and combine research into bilingualism with cultural, anthropological and humanistic linguistics. The paper closes with remarks on the perspectives of research on bi- and multilingualism in Poland. 